\title{
What is Needed for Correct Pronunciation: A Model or a Concern?
}

\author{
M. NACİ KAYAOĞLU* \\ Nuray ÇAYLAK**

\section{Suggested Citation:} \\ Kayaoğlu, M. N. \& Çaylak, N. (2013). What is needed for correct pronunciation: a \\ model or a concern? Egitim Arastirmalari-Eurasian Journal of Educational \\ Research, 53, 269-290.
}

\begin{abstract}
Problem Statement: Although the debate on adopting native-like pronunciation or a universal pronunciation is a change that can save nonnatives from embarrassment appears to have recently lost its merit, the challenge of teaching accurate and proper pronunciation is still a concern for teachers that needs to be remedied.

Purpose of Study: The main purpose of this study was to test the Audio Articulation Method as a remedy for pronunciation errors on adult EFL learners' acquisition of inter-dental fricatives / $\Theta /$ and / $/$ at a university vocational school. It also sought to explore the students' consideration of phonetic issues in language acquisition.
\end{abstract}

Methods: This quasi-experimental research was conducted at a vocational school of a Turkish university. A total of 36 students participated in the study. A pre-test / post-test design was employed so as to observe the effects of the method used in the experiment. In addition to a semistructured interview and classroom observation, a delayed post-test was conducted four weeks after the pre-test. SPSS 13.0 for Windows 2007 was used to analyze the data for a 0.05 significance level.

Findings and Results: The results of this study show a statistically significant difference in the students` pre-test and post-test scores. Similar significant results were also observed in the pre-test and delayed test scores, indicating a positive effect from the Audio Articulation Method. Yet, interestingly, nearly all students were observed to return to the same

\footnotetext{
* Corresponding Author. Asst. Prof. Dr., Department of English Language and Literature, Trabzon, Karadeniz Technical University, naci@ktu.edu.tr

** MA, Graduate School of Social Sciences, Trabzon, Karadeniz Technical University nuraycaylak@gmail.com
} 
pronunciation habits of inter-dental fricatives $/ \Theta /$ and /ð/ in routine classroom instruction after exposure to the Audio Articulation Method.

Conclusions: Learners were receptive to the acquisition of inter-dental fricatives $/ \Theta /$ and $/ ð /$, as the scores were positively correlated with the use of the Audio Articulation Method during the experiment. Nevertheless, the classroom observation data showed that students were not able to maintain their newly acquired phonetic behavior during routine English classes, which would indicate the need of long-term exposure to the newly acquired sounds/pronunciation.

Recommendations: This method is for the most part used for segmental level pronunciation errors, and as such it addresses a very limited part of the pronunciation issues and does not include stress, rhythm, intonation, connected speech, or prominence. Therefore, this method should more likely be considered as a complementary tool in addition to that of a pronunciation lesson.

Keywords: Audio-Articulation Method (AAM), inter-dental fricatives, pronunciation, pronunciation error

\section{Introduction}

"The Project of Developing Foreign Language Education" proposed by the Turkish Ministry of National Education aims to employ 3,000 Turkish Englishteachers abroad and 40,000 native speaker English teachers to work at schools in Turkey over the next four years. A similar project from the Council of Higher Education (Yüksek Ögrretim Kurulu Basın Odası, 2010) related to importing native speaker English instructors at universities to teach university English courses, as well as the adoption of the Common European Framework of Reference for Languages, have once again brought "pronunciation," a highly and mostly "neglected issue" (Saran, Seferoglu \& Cagiltay, 2009, p. 97), to the forefront for the agenda on language education. This paper does not adopt any particular side in the debate for whether a native or universal pronunciation should be taught, and does not pursue of giving answers to the questions raised by this debate.

There are a great number of studies regarding pronunciation instruction, some of them being only theoretical (Blanche, 2004; Hismanoglu, 2006; Jones, 1997; Milovanov, Pietila, Tervaniemi, and Esquef, 2010; Morgan, 2003; Munro and Derwing, 2006; Sicola, 2008; Tominaga, 2009; and Yao, 2008), some which test specific techniques (Kendrick, 1997; Trofimovich and Gatbonton, 2006; and Varasarin, 2007), and some which focus on the use of technology (Levis, 2007; Lord, 2008; Pennington, 1999; Pujolà, 2001; Saran et al., 2009; Saran and Seferoglu, 2010; and Seferoðlu, 2005) in pronunciation instruction. Common activities used in all studies are those that prescribe a model for pronunciation, such as listen and imitate, minimal pairs, visual aids, tongue twisters, developmental approximation drills, reading aloud/recitation, and recordings of learners' production. When recent studies are reviewed, it 
becomes apparent that supra-segmental aspects of pronunciation teaching are valued over segmental features, and intelligibility has become the objective of the pronunciation courses. In this regard, software programs which incorporate suprasegmental features for pronunciation and connected speech are now being designed in large volume. Seferoğlu (2005) suggests that pronunciation teaching/learning software programs have the potential to compensate for the lack of authentic input, practice, and interaction opportunities in the target language. In this sense, Seferoglu's study supports the view that technology can improve students' pronunciation at the segmental and supra-segmental levels. However, Seferoğlu (2005) stresses the importance of communicative activities in real life situations for retention and adaptability of pronunciation drills.

Inter-dental fricatives are not existent in most of the world's languages. The articulation of the inter-dental fricatives / $\Theta /$ and / $ð /$ are not only a serious pronunciation problem for EFL and ESL learners (Avery \& Ehrlich, 2003; Derwing and Rossiter, 2002; and Ur, 1996), but also they are the last sounds acquired by native-speaking children (Lombardi, 2003; Schmidt, 1977; and Wells, 1982, cited in Dubois \& Horvath, 1998). These are the sounds Turkish EFL learners have the most difficulty with as well (Demirezen, 2010b; and Rogerson-Revell, 2011). Inter-dental fricatives are not considered to create problems in terms of intelligibility (Jenkins, 2002; Rajafuai, 2006), yet, pose a serious problem for the quality of the language being spoken. Students who are not able to remove fossilized pronunciation mistakes cannot reach a high level of pronunciation in relation to both segmental and suprasegmental features of English pronunciation, or improve oral skills in terms of both accuracy and fluency, improve listening comprehension, and develop self-confidence and autonomy (Hismanoglu and Hismanoglu, 2010). Thus, English language teachers cannot ignore inter-dental fricatives when teaching pronunciation. Some studies regarding the acquisition of inter-dental fricatives are descriptive and aim to show the acquisition sequence (Burkardt, 2005) and interpret the results in terms of age, gender, and social network (Dubois and Horvath, 1998); other studies consider the issue in light of phonological hypotheses such as optimality theory (Wester, Gilbers, and Wander, 2007), markedness (Rau, Chang, and Tarone, 2009; and Wester et al., 2007), equivalence classification theory (Wester et al., 2007), and the variationist analytical approach (Rau et al., 2009).

Demirezen (2004) suggested the Audio-Articulation Method (AAM) as a solution to certain fossilized pronunciation mistakes. "In the pronunciation literature there is no method or model to rehabilitate the fossilized problem causing segmental phonemes of the target language within a class hour," and "the Audio-Articulation Method is designed to fill this gap in the field of pronunciation teaching" (Demirezen, 2010b, p.128). Demirezen (2004, 2005, 2007a, 2007b, 2008, 2010a, and $2010 b)$ put forward a number of model lessons for the Audio-Articulation Method (AAM) on the problematic sounds/pronunciation Turkish EFL learners usually face: $/ \Theta /, / \partial /, / \eta /$ and / $\mathrm{\eta k} /, / æ /$ and /Ә/, /æ/ and / $\Lambda /$, schwa, and palatalization. Hismanoglu (2007) proposed a lesson plan according to the AAM to remedy Turkish EFL learners` mispronunciation of the / : / and /ov/ sounds. Hismanoglu (2009) 
tested the AAM with / $\Theta /$ and /ð/ sounds and claimed that AAM did in fact rehabilitated students' inter-dentalization problem.

All of the aforementioned studies, which test the effect of AAM, recorded positive results. However, these studies do not inform us about the situation following the post-test and whether students return to their old pronunciation habits or not. We do not know whether the students maintain their newly acquired phonological behavior moving forward or lose it. In addition to the amount and type of the instruction, students attitudes, motivation, age, exposure, and concern for good pronunciation (Kenworthy, 1987) should be considered when evaluating the results of the experiment. To this end, the present study also aims to provide a qualitative dimension to the results with a delayed test, classroom observation, and a semi-structured interview.

\section{Audio-Articulation Method}

This model was presented by Demirezen (2004) in order to remedy fossilized pronunciation errors and designed for the students who study English Language Teaching at the university level. Dedicated to only pronunciation teaching, this model aims to rehabilitate the errors that occur at the segmental level in just one class, unlike other pronunciation teaching models (Demirezen, 2010b). Yet, Demirezen does not give the description of a reliable tool for diagnosing the fossilized errors. Thus, there is no clear way to decide whether the sounds under investigation are fossilized or not; in this respect "fossilization" as an opaque issue in and of itself renders the results more difficult on which to comment. To diagnose whether an error is fossilized, it is necessary to employ longitudinal studies and after confirming that certain sounds are fossilized, we should then implement the method and discuss whether or not it is effective in relation to evaluating these sounds. For this reason, the fossilization issue is excluded from the scope of this study and the AAM is used as a remedy for the pronunciation errors of students at the segmental level.

The activities include aural realization and discrimination of the sound pattern as well as the design of the practice procedures, which incorporate corpus, minimal pairs, minimal sentences, and sentential clues. Model lesson one is devoted to one or two specific sounds, and is approximately 45-50 minutes per class. The basic steps described by Demirezen (2010b) are as follows:

1. The foreign language teacher identifies the problematic core sound of the target language.

2. The teacher prepares a corpus of 50-100 words, including the problem causing core sound and its nearest pair.

3. S/he singles out minimal pairs from the corpus for practice.

4. S/he develops proper tongue twisters, proverbs, idioms, mottoes, or cliché expressions in chunks for classroom practice.

5. S/he stimulates further awareness and experiential practices within a suitable methodology. 


\section{Research Questions}

The purpose of this study is to test the effectiveness of the Audio-Articulation Method (Demirezen, 2004) for two of the most problematic sounds/pronunciation for Turkish EFL learners: the inter-dental fricatives $/ \Theta /$ and $/ ð /$. Answers to the following questions were specifically pursued:

1. Can Turkish elementary level EFL adult learners`mispronunciation of interdental fricatives be remedied by using the AAM?

2. Can this methodology provide the learners with awareness relating to phonological forms?

3. Does learners` pronunciation become target-like immediately after four weeks of exposure to this method?

4. Which variables determine the rate of the success and failure in the acquisition of the target pronunciation/sounds, $/ \Theta /$ and $/ ð /$, under investigation?

\section{Method}

Research Design

This quasi-experimental study was designed as pre-test/post-test, control comparison group model. To measure the long-term effects of the experiment and "to address to what extent the treatment truly resulted in learning" (Mackey \& Gass, 2005 , p.149), we included a delayed post-test after 4 weeks in addition to the immediate post-test.

Participants

A total of 36 first year elementary level students from a two-year higher education vocational school participated in this study. After forming a pool of volunteer students, 18 participants ( 8 male and 10 female) were randomly assigned to the control group and 18 participants (7 male and 11 female) were randomly assigned to the experimental group. Students` ages ranged from 19-26. They were from the departments of Computer Sciences, Tourism and Hotel Management, Accounting and Tax Applications, and Banking and Insurance Business.

Procedure

The aim of the experiment was to elicit the target sounds / $\Theta /$ and /ð/ in different contexts by means of two different tasks, namely, reading of a word list and reading of a passage in order to measure the effect of the context on the pronunciation of $/ \Theta /$ and /ð/ via a pre-test, post-test, and delayed test. Spontaneous data eliciting materials was not included after considering the level of the students.

Every test included the same target words but in different passages and wordlists. Word lists had 15 words that include the theta $/ \Theta /$ sound in each word first, middle, and final positions equally; and 15 words that include eth /ð/ sound in each position equally as well. The participants performed the tasks individually in a 
computer laboratory and handed them to the researcher, so as to create an atmosphere in which they felt relaxed during the recording. After the post-test, the experimental group received three class hours of pronunciation lessons $(45+45+45$ min.), as planned according to the AAM. Videos, songs, games, power point presentations, discrimination activities, and dialogue performances added to the lesson plans, and mirrors (Carruthers, 2007) were used during the practices with the thought of serving as a visual feedback for the students. Recording assignments also aimed to provide students with a linguistic awareness and a critical attitude towards the pronunciation of the target sounds in order to monitor their own pronunciation and give them a chance to continue to make gains in their own pronunciation. No feedback was given after the experiment in order to not contaminate the effect of the experiment. After the experiment, all students took the post-test, and four weeks after the post-test all of the participants took a delayed test. Only six volunteer students from the experimental group were interviewed. In addition to the aforementioned instruments, observations were recorded as field notes during the classes in the four week period between the post-test and the delayed test. Observation data and interview data were used in the discussion section.

Data Analysis

The pre-test, post-test, and delayed test received from all of the students in the experimental group and control group via computer were rated by three raters/researchers. The rate of agreement among the three raters was calculated with Kendall`s W test using SPSS 13.0 (Özdamar, 2011). The results were then analyzed by means of SPSS 13.0 for Windows 2007 using a one sample t-test to analyze the difference of means between the tests with a 0.05 significance level; descriptive statistics was employed to calculate the means and maximum rates of each test.

\section{Results}

\section{Quantitative Data}

The rate of agreement among the three raters is Kendall's $W=.088$. In the pre-test, there was no significant difference between the test scores of the control group and experimental group at the specified level $0.05, p=0.331$. In the post-test scores, there was a significant difference between the control group and experimental group at the specified level $0.05, p=0.007$. 


\section{Table 1}

Participants `Accuracy Rates for Pronouncing Target Sounds

\begin{tabular}{|c|c|c|c|c|c|c|}
\hline \multirow[t]{2}{*}{ Participants } & \multicolumn{2}{|c|}{ Pre-test } & \multicolumn{2}{|c|}{ Post-test } & \multicolumn{2}{|c|}{ Delayed test } \\
\hline & $f$ & $p$ & $f$ & $p$ & $f$ & $p$ \\
\hline 1 & $0 / 60$ & 0 & $14 / 60$ & 23.3 & $12 / 60$ & 20 \\
\hline 2 & $0 / 60$ & 0 & $12 / 60$ & 20 & $7 / 60$ & 11.6 \\
\hline 3 & $0 / 60$ & 0 & $0 / 60$ & 0 & $0 / 60$ & 0 \\
\hline 4 & $0 / 60$ & 0 & $17 / 60$ & 28.3 & $8 / 60$ & 13.33 \\
\hline 5 & $6 / 60$ & 10 & $29 / 60$ & 48.3 & $24 / 60$ & 40 \\
\hline 6 & $0 / 60$ & 0 & $0 / 60$ & 0 & $0 / 60$ & 0 \\
\hline 7 & $0 / 60$ & 0 & $0 / 60$ & 0 & $0 / 60$ & 0 \\
\hline 8 & $0 / 60$ & 0 & $0 / 60$ & 0 & $0 / 60$ & 0 \\
\hline 9 & $0 / 60$ & 0 & $42 / 60$ & 70 & $35 / 60$ & 58.33 \\
\hline 10 & $0 / 60$ & 0 & $18 / 60$ & 30 & $11 / 60$ & 18.33 \\
\hline 11 & $0 / 60$ & 0 & $0 / 60$ & 0 & $0 / 60$ & 0 \\
\hline 12 & $0 / 60$ & 0 & $0 / 60$ & 0 & $0 / 60$ & 0 \\
\hline 13 & $0 / 60$ & 0 & $0 / 60$ & 0 & $0 / 60$ & 0 \\
\hline 14 & $0 / 60$ & 0 & $0 / 60$ & 0 & $0 / 60$ & 0 \\
\hline 15 & $0 / 60$ & 0 & $0 / 60$ & 0 & $0 / 60$ & 0 \\
\hline 16 & $0 / 60$ & 0 & $12 / 60$ & 20 & $0 / 60$ & 0 \\
\hline 17 & $0 / 60$ & 0 & $5 / 60$ & 8.3 & $5 / 60$ & 8.3 \\
\hline 18 & $0 / 60$ & 0 & $29 / 60$ & 48.3 & $22 / 60$ & 36.6 \\
\hline
\end{tabular}

Frequency: $f$, Percentage: $p$

In the pre-test, with the exception of one student, for a $10 \%$ accurate pronunciation of target sounds $/ \Theta /$ and $/ ð /$, all participants failed. In the post-test, half of the participants ( 9 students) failed and half produced some of the target sounds. In the delayed test, with the exception of one participant (Participant 16), all students who succeeded in the post-test were successful in the delayed test (see Table 1). 
Table 2

Post-Test Test Scores for $/ \Theta /$ and /ð/

\begin{tabular}{|c|c|c|c|c|}
\hline \multirow[t]{2}{*}{ Post-test } & \multicolumn{2}{|c|}{ Table } & \multicolumn{2}{|c|}{ Passage } \\
\hline & $f$ & $p$ & $f$ & $p$ \\
\hline Thursday & 3 & 16.7 & 1 & 5.6 \\
\hline Think & 3 & 16.7 & 2 & 11.1 \\
\hline Three & 2 & 11.1 & 3 & 16.7 \\
\hline Thin & 4 & 22.2 & 3 & 16.7 \\
\hline Thank & 4 & 22.2 & 4 & 22.2 \\
\hline Something & 2 & 11.1 & 2 & 11.1 \\
\hline Everything & 4 & 22.2 & 4 & 22.2 \\
\hline Nothing & 4 & 22.2 & 3 & 16.7 \\
\hline Wealthy & 5 & 27.8 & 3 & 16.7 \\
\hline Healthy & 5 & 27.8 & 3 & 16.7 \\
\hline Month & 6 & 33.3 & 2 & 11.1 \\
\hline Earth & 4 & 22.2 & 1 & 5.6 \\
\hline Bath & 4 & 22.2 & 4 & 22.2 \\
\hline North & 7 & 38.9 & 3 & 16.7 \\
\hline Path & 5 & 27.8 & 0 & .00 \\
\hline They & 0 & .00 & 1 & 5.6 \\
\hline That & 1 & 5.6 & 0 & .00 \\
\hline Though & 2 & 11.1 & 2 & 11.1 \\
\hline Those & 2 & 11.1 & 4 & 22.2 \\
\hline There & 1 & 5.6 & 0 & .00 \\
\hline Weather & 4 & 22.2 & 2 & 11.1 \\
\hline Father & 4 & 22.2 & 4 & 22.2 \\
\hline Mother & 4 & 22.2 & 4 & 22.2 \\
\hline Brother & 5 & 27.8 & 4 & 22.2 \\
\hline Together & 5 & 27.8 & 0 & .00 \\
\hline Clothe & 6 & 33.3 & 1 & 5.6 \\
\hline Bathe & 6 & 33.3 & 2 & 11.1 \\
\hline Breathe & 3 & 16.7 & 2 & 11.1 \\
\hline Loathe & 4 & 22.2 & 1 & 5.6 \\
\hline Wreathe & 1 & 5.6 & 3 & 16.7 \\
\hline
\end{tabular}

Note: $\mathrm{N}=18$

Frequency: $f$, Percentage: $p$

In the post-test word list, "north" was the most accurately pronounced word by 7 participants; followed by month, clothe, and bathe (6); "they" did not gain any rate. In the post-test passage, thank, everything, bath, those, father, mother, and brother gained 
the highest scores (4), and together, that, and there did not gain any rate. The minimum rate was 0 and the maximum rate is 7 . There was no word left unpronounced in the whole test (see Table 2).

\section{Table 3}

Delayed-Test Test Scores for $/ \theta /$ and /ð/

\begin{tabular}{|c|c|c|c|c|}
\hline \multirow[t]{2}{*}{ Delayed test } & \multicolumn{2}{|c|}{ Table } & \multicolumn{2}{|c|}{ Passage } \\
\hline & $f$ & $p$ & $f$ & $p$ \\
\hline Thursday & 2 & 11.1 & 1 & 5.6 \\
\hline Think & 3 & 16.7 & 2 & 11.1 \\
\hline Three & 4 & 22.2 & 2 & 11.1 \\
\hline Thin & 3 & 16.7 & 3 & 16.7 \\
\hline Thank & 1 & 5.6 & 2 & 11.1 \\
\hline Something & 2 & 11.1 & 0 & 0 \\
\hline Everything & 2 & 11.1 & 1 & 5.6 \\
\hline Nothing & 3 & 16.7 & 1 & 5.6 \\
\hline Wealthy & 4 & 22.2 & 4 & 22.2 \\
\hline Healthy & 2 & 11.1 & 2 & 11.1 \\
\hline Month & 3 & 16.7 & 2 & 11.1 \\
\hline Earth & 4 & 22.2 & 4 & 22.2 \\
\hline Bath & 4 & 22.2 & 5 & 27.8 \\
\hline North & 3 & 16.7 & 1 & 5.6 \\
\hline Path & 3 & 16.7 & 1 & 5.6 \\
\hline They & 0 & 0 & 1 & 5.6 \\
\hline That & 0 & 0 & 1 & 5.6 \\
\hline Though & 2 & 11.1 & 1 & 5.6 \\
\hline Those & 1 & 5.6 & 2 & 11.1 \\
\hline There & 0 & 0 & 0 & 0 \\
\hline Weather & 2 & 11.1 & 1 & 5.6 \\
\hline Father & 3 & 16.7 & 2 & 11.1 \\
\hline Mother & 3 & 16.7 & 2 & 11.1 \\
\hline Brother & 4 & 22.2 & 4 & 22.2 \\
\hline Together & 4 & 22.2 & 3 & 16.7 \\
\hline Clothe & 2 & 11.1 & 1 & 5.6 \\
\hline Bathe & 0 & 0 & 1 & 5.6 \\
\hline Breathe & 3 & 16.7 & 1 & 5.6 \\
\hline Loathe & 2 & 11.1 & 0 & 0 \\
\hline Wreathe & 2 & 11.1 & 2 & 11.1 \\
\hline
\end{tabular}

Note: $\mathrm{n}=18$

Frequency: $f$, Percentage: $p$ 
In the delayed-test word list, thank, everything, bath, those, father, mother, and brother gained the highest scores (4), and they, bath, that, and there did not gain any rate. In the delayed-test passage, "bath" received the highest score (5) and wealthy, earth, and brother followed it (4), and something, loathe, and there did not gain any rate. The minimum rate was 0 and the maximum rate is 5 , but there was a slight decrease in the maximum score. There was just one word (there) left unpronounced in the test (see Table 3).

\section{Table 4}

Mean and Percentages of Theta $/ \Theta /$ and Eth $/ \partial /$ Sound, Rates for the Beginning, Middle, and End of Words

\begin{tabular}{|c|c|c|c|c|c|}
\hline & $M$ & $P$ & & $M$ & $P$ \\
\hline $\begin{array}{l}\text { Post-test } \\
\text { word-initially } \\
\text { theta sound }\end{array}$ & $1.7222 / 60$ & 2.870 & $\begin{array}{l}\text { Delayed-test } \\
\text { word-initially } \\
\text { theta sound }\end{array}$ & $1.2778 / 60$ & 2.129 \\
\hline $\begin{array}{l}\text { Post-test } \\
\text { word-medially } \\
\text { theta sound }\end{array}$ & $1.9444 / 60$ & 3.240 & $\begin{array}{l}\text { Delayed-test } \\
\text { word-medially } \\
\text { theta sound }\end{array}$ & $1.1667 / 60$ & 1.944 \\
\hline $\begin{array}{l}\text { Post-test } \\
\text { word-finally } \\
\text { theta sound }\end{array}$ & $2.0000 / 60$ & 3.333 & $\begin{array}{l}\text { Delayed-test } \\
\text { word-finally } \\
\text { theta sound }\end{array}$ & $1.6667 / 60$ & 2.777 \\
\hline $\begin{array}{l}\text { Post-test } \\
\text { total theta sound }\end{array}$ & $5.6667 / 60$ & 9.444 & $\begin{array}{l}\text { Delayed-test } \\
\text { total theta sound }\end{array}$ & $4.1111 / 60$ & 6.851 \\
\hline $\begin{array}{l}\text { Post-test } \\
\text { word-initially } \\
\text { eth sound }\end{array}$ & $.6111 / 60$ & 1.018 & $\begin{array}{l}\text { Delayed-test } \\
\text { word-initially } \\
\text { eth sound }\end{array}$ & $.4444 / 60$ & .740 \\
\hline $\begin{array}{l}\text { Post-test } \\
\text { word-medially } \\
\text { eth sound }\end{array}$ & $2.0000 / 60$ & 3.333 & $\begin{array}{l}\text { Delayed-test } \\
\text { word-medially } \\
\text { eth sound }\end{array}$ & $1.5556 / 60$ & 2.592 \\
\hline $\begin{array}{l}\text { Post-test } \\
\text { word-finally } \\
\text { eth sound }\end{array}$ & $1.6111 / 60$ & 2.685 & $\begin{array}{l}\text { Delayed-test } \\
\text { word-finally } \\
\text { eth sound }\end{array}$ & $.7778 / 60$ & 1.296 \\
\hline $\begin{array}{l}\text { Post-test } \\
\text { total eth sound }\end{array}$ & $4.2222 / 60$ & 7.037 & $\begin{array}{l}\text { Delayed-test } \\
\text { total eth sound }\end{array}$ & $2.7778 / 60$ & 4.629 \\
\hline
\end{tabular}

Mean: $M$, Percentage: $P$

Table 4 shows that theta $/ \Theta /$-words with the sound in the final part of the word gained the highest score both for the post-test (3.333\%) and the delayed-test $(2.777 \%)$. Eth/ $ð$ / with the sound in the middle part of the word gained the highest scores 
both in the post-test $(3.333 \%)$ and delayed test $(2.592 \%)$. The results indicates that the participants are more successful in pronouncing the eth sound when it is in the middle of the word, and as for theta sound, beginning and end of the words are easier to pronounce for the participants.

Table 5

Mean and Percentages of Theta $/ \Theta /$ and Eth /ð/Sounds

\begin{tabular}{lcc}
\hline & $M$ & $p$ \\
\hline Post-test and pre-test total theta sound & $9.7778 / 60$ & 16.296 \\
Post-test and pre-test total eth sound & $7.0000 / 60$ & 11.666 \\
\hline
\end{tabular}

Mean: $M$, Percentage: $p$

For all tests, theta $/ \Theta /$ sounds gained the highest score. The result indicates that participants are more successful in the pronunciation of the theta sound when overall scores are considered (see Table 5).

Table 6

Descriptive Statistics, Mean, Standard Deviation and Maximum Rates

\begin{tabular}{lccccc}
\hline & $\boldsymbol{N}$ & $\boldsymbol{M}$ & $\mathrm{SD}$ & Minimum & Maximum \\
\hline Total Pre-test & 18 & .3333 & 1.41421 & .00 & 6.00 \\
Total Post-test & 18 & 9.8889 & 12.85159 & .00 & 42.00 \\
Total Delayed test & 18 & 6.8889 & 10.38601 & .00 & 35.00 \\
\hline
\end{tabular}

Mean: $M$

When the overall means are estimated, it can be seen that the post-test gained the highest mean and in the delayed test there was a decrease in the mean (see Table 6). The results show that participants could not keep the newly learned phonetic behavior at the same level after the instruction. 
Table 7

Comparison of the Means of Pre-Test and Post-Test

\begin{tabular}{|c|c|c|c|c|c|c|}
\hline & \multicolumn{6}{|c|}{ Test Value $=0.33$} \\
\hline & \multirow[t]{2}{*}{$t$} & \multirow[t]{2}{*}{$d f$} & \multirow[t]{2}{*}{ Sig. (2-tailed) } & \multirow[t]{2}{*}{$\begin{array}{l}\text { Mean } \\
\text { Difference }\end{array}$} & \multicolumn{2}{|l|}{$95 \% C I$} \\
\hline & & & & & Lower & Upper \\
\hline $\begin{array}{l}\text { Total } \\
\text { Posttest }\end{array}$ & 3.156 & 17 & .006 & 9.55889 & 3.1679 & 15.9498 \\
\hline
\end{tabular}

Mean: $M$, Confidence Interval of the Difference: $\mathrm{CI}$

When the pre-test and post-test are compared, there is a statistically significant difference between the two test scores at the specified level .05, $t=3.156, p=.006,95 \%$ CI [3.1679, 15.9498] (see Table 7). The results suggest that the instruction has a remarkable effect on the phonetic behavior of the participants.

\section{Table 8}

Comparison of the Means of Post-Test and Delayed Test

\begin{tabular}{|c|c|c|c|c|c|c|}
\hline & \multicolumn{6}{|c|}{ Test Value $=9.88$} \\
\hline & $t$ & $d f$ & Sig. (2-tailed) & $M$ & $95 \% C I$ & \\
\hline & & & & & Lower & Upper \\
\hline $\begin{array}{l}\text { Total } \\
\text { Delayed } \\
\text { Test }\end{array}$ & -1.222 & 17 & .238 & -2.99111 & -8.1560 & 2.1737 \\
\hline
\end{tabular}

Mean: $M$, Confidence Interval of the Difference: $\mathrm{CI}$

Table 8 displays that when the post-test and the delayed-test are compared, the data shows statistically no significant difference between the two test scores at the specified level $.05, t=-1.222, p=.238,95 \%$ CI [-8.1560, 2.1737]. The results propose that the instruction model is persistent on the phonetic behavior of the participants.

\section{Table 9}

Comparison of the Means of Pre-Test and Delayed Test

\begin{tabular}{|c|c|c|c|c|c|c|}
\hline & \multicolumn{6}{|c|}{ Test Value $=.33$} \\
\hline & $t$ & $d f$ & Sig. (2-tailed) & $M$ & $\begin{array}{l}95 \% \text { CI } \\
\text { Lower }\end{array}$ & Upper \\
\hline $\begin{array}{l}\text { Total } \\
\text { Delayed } \\
\text { Test }\end{array}$ & 2.679 & 17 & .016 & 6.55889 & 1.3940 & 11.7237 \\
\hline
\end{tabular}

Mean: $M$, Confidence Interval of the Difference: $\mathrm{CI}$ 
The one-sample $t$-test in Table 9 displays the comparison between the pre-test and the delayed test, and the data shows a statistically significant difference at the specified .05 level, $t=2.679, p=.016,95 \%$ CI [1.3940, 11.7237]. The results indicate that participants carried out their newly required phonetic behavior.

\section{Qualitative Data}

Qualitative data for the study was obtained through semi-structured interviews conducted with six students and structured observations (Cohen et al., 2007; Dörnyei, 2007). With the interviews and structured observations, the aim was to acquire a wider snapshot of the results of the quantitative data.

Students who participated in this study were observed for four weeks after the post-test. They read passages which had similar content with the passages used in the tests. Students were checked to see whether they pronounced the target sounds, inter-dental fricatives $/ \Theta /$ and /ð/. With the exception of four students in the first week and two in the second, third, and forth weeks, none of the students used the target sounds, inter-dental fricatives.

As for interviews, it is clear that the English learning experiences of the students who participated in the interviews share a common ground: taking English classes from teachers without an English background, test-based learning, and lack of exposure to authentic listening materials and no speaking opportunities at all. Nearly all participants were deprived of any regular or qualified English lessons during their primary and high school education. Most of the students come from vocational high schools, where English class hours are even less when compared to other schools and are considered quite useless when compared to the other vocational lessons. Students complain about teachers who have no English background:

"At high school our history teacher tried to teach us English, in fact we tried to learn it all together" (Student F).

"In the first year of my learning English was not a good experience because my visual arts teacher was teaching us English..." (Student H).

Pronunciation as the stepdaughter of language teaching suffers much from being given the least importance. Students learn with great effort but easily forget; they need consistent and constant education in the related subject. Some of the students had actually never even heard the target sounds used in this study before. In addition, none of them had articulated the sounds before.

"I have never heard these sounds before; none of my teachers have taught me these sounds. So now it is difficult for me to remember it whenever I read something in English or speak in English" (Student A).

"This is the first time I heard this sound, I try to use it" (Student T).

When students were asked the reason of not using "the" sound that they learned in the experiment, they complained about not having been taught it at the beginning of their English instruction, and once again saw no profit in finding a reason to study 
the "why" for pronunciation of the English language and why it is considered very important at the university level:

"They should have taught it many years ago, at the beginning, they said us pronounce it this way now they say do it that way" (Student B).

"I try to sound like natives when acting a dialogue to make my friends laugh otherwise I do not use, because it is not accepted among boys" (Student T).

"Because this is something that I never spoke before, so hearing my own voice in that way sounds a bit strange and ridiculous to me. I am not accustomed to it" (Student B).

Pronunciation errors are not corrected or emphasized consistently by teachers. Teachers mostly focused on other language skills and push pronunciation to the background. This attitude affects the students`attitude towards pronunciation, and students also pay little or no attention to it.

"Teachers also give much importance to grammar and vocabulary; they do not demand a good pronunciation from the students" (Student T).

"Teachers do not give positive feedback when we pronounce a word right or read a passage fluently. They just say "well done" when we did an exercise right, or answer a question grammatically and right" (Student B).

"Why would I bother pronunciation, teacher does not assess and give grades to my pronunciation?" All the exams are based on grammar etc not on pronunciation. I revise the sentence learn to the extent I need. When I say/tenk yu/ tourists can understand me so why should I bother myself saying /Oenk yu/" (Student M).

Many hours have been spent on English language tuition from the $4^{\text {th }}$ grade in primary schools all the way through to the university level, and yet a large majority of the students are unable to express themselves orally, resulting in negative attitudes towards English.

\section{Discussion and Conclusion}

The present study has attempted to test the learners` acquisition of inter-dental fricatives through the AAM. Statistically, the results yielded similar results in concordance with previous studies (Hismanoglu, 2009). 45+45+45 minute pronunciation lesson with the AAM rehabilitated students` pronunciation problems with inter-dental fricatives were implemented. The results indicate that the AAM is effective for solving the pronunciation problems of students and helps them gain phonological awareness towards the target sounds / $\Theta /$ and /ð/. However, nearly half of the students that recorded significant achievement in acquiring inter-dental fricatives were observed to revert to their previous habits of pronunciation in classroom activities during the four week period between the post-test and delayed 
test. Nevertheless, the students pronounced the target sounds when they were assessed in the post-test and delayed test portion of the experiment. This situation suggests that students have the capability to pronounce these sounds even when they do not pronounce them. In light of the evidence from the interviews, we can say there are a number of reasons behind the students' not using these sounds during classroom activities. The interview data indicates that students have little awareness towards good pronunciation in English lessons. While they agree with the commonly held idea that pronunciation is important, according to their own particular understanding as students, pronunciation is not important because it is not assessed. As the curriculum suggests, teaching pronunciation is considered a luxury exercise in the midst of teaching other skills. In primary and high schools, pronunciation teaching is a peripheral element, as is the test-oriented culture in the education system. Thus, the learners come to university with low proficiency in pronunciation. Students who participated in this study have not received any pronunciation training or consistent feedback on their pronunciation, which has resulted in the false automatization of their earlier education. Nevertheless, they recorded statistically significant successes in their pronunciation of inter-dental fricatives / $\Theta /$ and /ð/ sounds. This result indicates that the students are receptive; hence, their pronunciation mistakes can be remedied through the AAM and follow up practice.

The students need constant practice and feedback to reach a certain comfort level and automaticity. No feedback was given in the four week period between the pretest and the post-test in order to observe the lasting effect of the method. The method suggests remedying errors in a lesson hour, for this reason it requires observing its effect after the model lesson. This factor can be considered as one of the main reasons for the students failure in practice. Instructions should be followed by controlled practicing, and then guided practice, and finally communicative practice and accompanying feedback in all steps (Celce-Murcia, 2010) in order to sustain a lasting change. For this computers will be valuable assistants to language teachers by helping students become autonomous with endless opportunities for repetition and the practice of sounds, visualized feedback, and visual support to enhance articulation, in addition to the chance to record and compare students ' pronunciation against a model version (Rogerson-Revell, 2011). Recording exercises can be compounded with error diaries which students keep after listening to their own voices or recordings from their friends, thus forming a pronunciation corpus. Drama and humor will complement visual and kinesthetic practices by helping students to digest the newly acquired sound and phonologic features (Rogerson-Revell, 2011).

The AAM is for the most part pertinent to segmental level pronunciation mistakes, and it addresses only a very limited part of the pronunciation issue among stress, rhythm intonation, connected speech, and prominence; it is not a complete method that addresses all aspects of pronunciation teaching. In turn it fails to consider the issue of feedback and automatization, both of which are vital to remedying pronunciation errors and ensuring lasting change. Consequently, this method should more likely be considered as a complementary tool, as well as a pronunciation lesson, rather than a complete method for teaching pronunciation by itself. 
Considering the changes on the perspective of education in terms of placing emphasis on native instructors, and the development of technology and the mobility, the pronunciation issue will gain its position of importance in time. Pronunciation teaching cannot be considered to be a luxury in education any more with the assistance of computers, which are tireless and full-time teachers for learners.

When the teacher gives importance to pronunciation, students do, as well. Concern for good pronunciation is something that teachers can instill in students. Learners` motivation and awareness, in addition to their appreciation for the gravity of correct pronunciation, hold crucial importance in pronunciation improvement. Unless the learners take the responsibility for their own success, their results will be far from satisfactory.

Pronunciation should be integrated into all aspects of language teaching and classes even though it is taught as a separate lesson. Students should take feedback not only when they practice pronunciation, but also when they use language in other parts of the lesson as well. Additionally, a separate class for pronunciation will also guarantee that students attach importance to pronunciation (Naiman, 2003). Analyzing students' resources and present situations should be the guide in balancing the focus and mode of pronunciation instruction. Errors do not give way to permanent change so easily; it takes time and regular control, and improves in stages. Patience and concern, however, can help to change the picture.

\section{References}

Avery, P., \& Ehrlich, S. (2003). Teaching American English pronunciation. Oxford: Oxford University Press.

Blanche, P. (2004). Using dictation to teach pronunciation. Linguagem E Ensino, 7(1), 175-191.

Burkardt, B. A. (2005). Acquisition sequence of the English interdental fricatives by Thai ESL learners. (Unpublished master's thesis). Southern Illinois University, Carbondale.

Carruthers, S.W. (2007). Articulatory training on facial movements using the webcam pronunciation mirror: A pilot study. TESOL Working Paper Series, 5(1), 3-18.

Celce-Murcia, M., Brinton, D. M., Goodwin, J. M., \& Griner, B. (2010). Teaching pronunciation: A course book and reference guide (2nd ed.). Cambridge: Cambridge University Press.

Cohen, L., Manion, L., \& Morrison, K. (2007). Research methods in education (6 th $^{\text {ed. }}$.). Oxon: Routledge. 
Demirezen, M. (2004). İngilizce`nin peltek-d (eth) ses biriminin Türkler için çıkardığı sesletim sorunları ve çözümler. [Difficulties of the English sound /ð/ for Turks and solutions] Çankaya Universitesi Fen-Edebiyat Fakultesi, Journal of Arts and Science, 1(1), 7-22.

Demirezen, M. (2005). Palatalization in English: an articulation problem for Turkish teacher trainees. Journal of Language and Linguistic Studies, 1(1), 43-52.

Demirezen, M. (2007a). A model to rehabilitate a fossilized pronunciation error of Turkish English language teachers: the English consonant phoneme / $\mathrm{y} /$ wrongly articulated as $/ \mathrm{nk} /$ through nasal devoicing. Journal of Language and Linguistic Studies, 3(2), 289-303.

Demirezen, M. (2007b). The / æ / and / $\square$ / contrast as a case of fossilized pronunciation error for Turkish English teachers. Journal of Language and Linguistic Studies, 3(1), 81-96.

Demirezen, M. (2008). The /æ/ and $/ \wedge /$ phonemes as fossilized pronunciation errors for Turkish English language teachers and students: undoing the fossilized pronunciation. Journal of Language and Linguistic Studies, 4(2), 73-82.

Demirezen, M. (2010a). The causes of the schwa as a fossilized pronunciation problem for Turks. Procedia Social and Behavioural Sciences 2, 567-1571.

Demirezen, M. (2010b). The principles and applications of the Audio-lingual pronunciation rehabilitation model in foreign language teacher education. Journal of Language and Linguistic Studies, 6(2), 127-148.

Derwing, M. T., \& Rossiter, M. J. (2002).ESL learners' perceptions of their pronunciation needs and strategies. System 30, 155-166.

Dörnyei, Z. (2007). Research methods in applied linguistics. Oxford: Oxford University Press.

Dubois, S., \& Horvath, B. M. (1998). Let's tink about dat: Interdental fricatives in Cajun English. Language Variation and Change, 10, 245-261.

Hismanoglu, M. (2006). Current perspectives on pronunciation learning and teaching. Journal of Language and Linguistic Studies, 2(1), 101-110

Hismaoglu, M. (2007). The / :/ and /ə $/$ / Contrast as a fossilized pronunciation error of Turkish learners of English and solutions to the problem. Journal of Language and Linguistic Studies, 3(1), 98-116

Hismanoglu, M. (2009). The pronunciation of the inter-dental sounds of English: An articulation problem for Turkish learners of English and solutions. Procedia Social and Behavioural Sciences 1, 1697-1703. 
Hismanoglu, M., \& Hismanoglu, S. (2010). Language teachers` preferences of pronunciation teaching techniques: Traditional or modern? Procedia Social and Behavioural Sciences 2, 983-989.

Jenkins, J. (2002). A sociolinguistically based, empirically researched pronunciation syllabus for English as an international language. Applied Linguistics, 23(1), 83103.

Jones, R. H. (1997). Beyond "listen and repeat": Pronunciation teaching materials and theories of second language acquisition. System, 25(1), 103-112.

Kendrick, H. (1997). Keep them talking! A project for improving students` L2 pronunciation. System, 25(4), 545-560.

Kenworthy, J. (1987). Teaching English pronunciation. London: Longman.

Lombardi, L. (2003). Second language data and constraints on manner: Explaining substitutions for the English interdentals. Second Language Research, 19(3), 225250 .

Levis, J. (2007). Computer technology in teaching and researching pronunciation. Annual Review of Applied Linguistics 27, 184-202.

Lord, LG. (2008). Podcasting communities and second language pronunciation. Foreign Language Annals, 41(2), 364-379.

Mackey, A., Gass, S. (2005). Second language research: Methodology and design. New Jersey: Lawrence Erlbaum Associates Publishers.

Milovanov, R., Pietila, P., Tervaniemi, M., \& Esquef, P. A. A. (2010). Foreign language pronunciation skills and musical aptitude: A study of Finnish adults with higher education. Learning and Individual Differences, 20, 56-60.

Morgan, C. (2003). Musical aptitude and second language phonetics training: Implications for teaching methodology. (Unpublished doctoral dissertation). Simon Fraser University, Bornaby.

Munro, M .J., \& Derwing, M. T. (2006). The functional load principle in ESL pronunciation instruction: An exploratory study. System, 34, 520-531.

Naiman, N. (2003). A communicative approach to pronunciation teaching. In P. Avery \& S. Ehrlich (Eds.) Teaching American English pronunciation, (pp. 163171). Oxford: Oxford University Press.

Özdamar, K. (2011). Paket programlar ile istatistiksel veri analizi (8th ed) [Statistical data analysis with package programmes]. Eskişehir: Kaan Kitabevi. 
Pennington, M. C. (1999). Computer-aided pronunciation pedagogy: Promise, limitations, directions. Computer Assisted Language Learning, 12(5), 427-440.

Pujolà, J. (2001). Did CALL feedback feed back? Researching learners' use of feedback. ReCALL, 13 (1), 79-98.

Rajadurai, J. (2006). Pronunciation issues in non-native contexts: A Malaysian case study. Malaysian Journal of ELT Research, 2, 42-59.

Rau, D.V., Chang, H. H. A., \& Tarone, E. E. (2009). Think or sink: Chinese learners acquisition of the English voiceless inter-dental fricative. Language Learning, 59(3), 581-621.

Rogerson-Revell, P. (2011). English phonology and pronunciation teaching. London, UK: Continuum.

Saran, M., \& Seferoğlu, G. (2010). Yabancı dil sözcük öğreniminin çoklu ortam cep telefonu iletileri ile desteklenmesi [Supporting foreign language vocabulary learning through multimedia messages via mobile phones]. Hacettepe Üniversitesi Ĕ̆itim Fakültesi Dergisi (H. U. Journal of Education) 38, 252-266.

Saran, M., Seferoglu, G., \& Cagiltay, K. (2009). Mobile assisted language learning:

English pronunciation at learners' fingertips. Eğitim Araştırmaları-Eurasian

Journal of Educational Research, 34, 97-114.

Seferoğlu, G. (2005). Improving students' pronunciation through accent reduction software. British Journal of Educational Technology, 13(1), 303-316.

Schmidt, R. (1977). Sociolinguistic variation and language transfer in phonology. Amsterdam: University of Amsterdam.

Sicola, L. (2008). "No, they won't just sound like each other!" NNS-NNS negotiated interaction and attention to phonological form on targeted L2 pronunciation tasks. (Unpublished doctoral dissertation). University of Pennsylvania, Graduate School of Education, Language and Literature: Language and Linguistics, Philadelphia.

Tominaga, Y. (2009). An analysis of successful pronunciation learners: In search of effective factors in pronunciation teaching. Journal of pan-Pacific Association of Applied Linguistics, 13(1), 127-140.

Trofimovich, P. \& Gatbonton, E. (2006). Repetition and focus on form in processing L2 Spanish words: Implications for pronunciation instruction. The Modern Language Journal, 90, 519-535.

Ur, P. (1996). A course in language teaching. Cambridge: Cambridge University Press. 
Varasarin, P. (2007). An action research study of pronunciation training, language learning strategies and speaking confidence. (Unpublished doctoral dissertation). Victoria University, School of Education, Faculty of Arts, Education and Human Development, Melbourne.

Wester, F., Gilbers, D., \& Wander, L. (2007). Substitution of dental fricatives in English by Dutch L2 speakers. Language Sciences, 29, 477-491.

Yao, H. (2008). An interview study of native Chinese-speaking English as a foreign language university students experience of acquiring English pronunciation. (Unpublished doctoral dissertation). University of Kansas, School of Liberal Arts and Sciences, Lawrence.

Yükseköğretim Kurulu Basın Odası (2010, August 11). Yükseköğretim kurulu başkanliği fulbright işbirliği programı [Higher Education Council Fullbright cooperation Program]. Retrieved August 11, 2010 from

https:/ /basin.yok.gov.tr/?page $=$ duyurular\&v $=$ read $\& \mathrm{i}=170$

\section{Telaffuz Eğitimi bir Model ya da İlgi Sorunu mu?}

Atıf:

Kayaoğlu, M. N. \& Çaylak, N. (2013). What is needed for correct pronunciation: a model or a concern? Egitim Arastirmalari-Eurasian Journal of Educational Research, 53, 269-290.

\section{Özet}

Problem Durumu: Telaffuz eğitiminde, doğal konuşmacı olmayanları idealizmin yarattığı sıkıntıdan kurtaracağını vadeden evrensel telaffuzun mu yoksa doğala-yakın telaffuzun mu benimsenmesi gerektiği konusundaki tartışmalar kısmen ivme kaybetmiş olsa da, telaffuz öğretiminde ve telaffuz hatalarının düzeltilmesinde karşılaşılan sorunlar yabancı dil ögrretmenleri için hala problem arz etmektedir.

Araştırmanın Amacı: Bu araştırmanın amacı, tek derste telaffuz hatalarına çare olarak tasarlanmış Duy-seslet Yöntemi'nin üniversite öğrencilerinin İngilizcedeki peltek $\mathrm{t}$ / $\Theta /$ ve peltek d /ð/ sesleriyle ilgili telaffuz hatalarının giderilmesi konusunda uzun vadedeki etkililiği incelemektir. Aynı zamanda çalışmada öğrencilerin telaffuz konusundaki tutumlarının tespit edilmesi de amaçlanmaktadır.

Araştırmanın Yöntemi: Bu çalışma yarı-deneysel yönteme göre yapılandırılmıştır. Çalışmaya, 18'i deney gurubunda 18'i gözlem gurubunda olmak üzere toplam 36 üniversite öğrencisi katılmıştır. Çalışmada ön-test, son-test modeli kullanılmış ve uygulanan deneysel yöntemin uzun vadeli etkilerinin incelenmesi amaciyla son-testten dört hafta sonra geciktirmeli test uygulanmıştır. Ön-testin ardından deney gurubun- 
daki öğrenciler 50+50 dakikalık Duy-seslet Yöntemine göre planlanmış deneysel derse katılmışlardır. Duy-seslet Yöntemi 50 dakikalık bir ders planından oluşmaktadır fakat bu çalışmada ders planı ilave alıştırma ve videolarla desteklenerek 50+50 dakikalık ders şeklinde planlanmıştır. Dersler birbirini takip edecek şekilde iki ayrı günde yapılmıştır. Deneyin ardından katılımcıların tamamına son-test uygulanmıştır. Son-test ile geciktirilmiş test arasındaki dört haftalık dönemde öğrencilerin hedef sesleri telaffuz edip etmediklerini kontrol etmek amacıyla sınıf içi yapılandırılmış gözlem yapılmıştır. Dördüncü hafta sonunda öğrencilerin tamamı geciktirilmiş teste katılmıştır. Çalışmada kullanılan testler iki bölümden oluşmaktadır, ilk kısımda hedef sesler olan peltek $t / \Theta$ / ve peltek $d$ / ð / seslerini içeren bir tablonun okunması ve ikinci kısımda da yine bu sesleri içeren ortalama 200 kelimelik bir okuma parçasının okunması yer almaktadır. Hem tablo hem de okuma parçası aynı oranda hedef ses içeren kelimelerden oluşmaktadır. Tüm testlerde aynı kelimelerden oluşturulan okuma parçaları ve tablolar kullanılmıştır. Tabloda ve okuma parçasında ayrı ayrı olmak üzere peltek $\mathrm{t} / \Theta /$ 'nin kelimenin başında, ortasında ve sonunda kullanıldığı 15 sözcük ve aynı şekilde peltek d / ð /'nin kelimenin başında, ortasında ve sonunda kullanıldığı 15 sözcük yer almaktadır. Veriler bilgisayara kaydedilmiş ve üç araştırmacı tarafından puanlanmıştır. Araştırmacıların puanlamaları arasındaki korelasyonun güvenirliği Wendall's K, SPSS 13.0 ile ölçülmüştür. Verilerin analizi “Onesample t-test" ve "Descriptive Statistics" teknikleriyle yapılmış ve SPSS 13.0 progra$\mathrm{m}$ kullanılmıştır. Sonuçların yorumlanmasında $\mathrm{p}<0.05$ anlamlılık düzeyi üst değer olarak alınmıştır. Testlere ek olarak sınıf içi yapılandırılmış gözlem ve altı gönüllü öğrenciyle yarı yapılandırılmış mülakat uygulanmıştır. Mülakatta öğrencilerin telaffuzla ilgili tutumları ve görüşleri ele alınmıştır. Sınıf içi yapılandırılmış gözlemde ise testlerde kullanılan okuma parçalarıyla aynı izlek uygulanmıştır, öğrencinin gözleme karşı uyarılmaması için gözlem listesi kullanılmıştır.

Araştırmanın Bulguları: Deneysel dersin öncesinde deney ve kontrol guruplarının öntest puanları arasında anlamlı bir farklılığın bulunmadığı saptanmıştır $(p=0.331>0.02)$. Çalışmanın sonucunda deney gurubundaki öğrencilerim ön-test ve son-test puanları arasında istatistiksel açıdan pozitif fark görülmüştür $(p=0.006<0.02)$ ve bu farkın geciktirmeli test sonuçlarında da devam ettiği görülmüştür. Deney ve kontrol guruplarının son-test puanları arasındaki farkın anlamlı olduğu saptanmıştır $(p=0.007<0.02)$. Bu sonuç Duy-seslet Yönteminin katılımcılar üzerinde etkili olduğunu ortaya koymaktadır. Fakat Duy-seslet Yönteminin uygulandı̆̆1 deneyden sonra son-test ve geciktirmeli test arasındaki dört haftalık sürede yapılan yapılandırılmış sınıf içi gözlemde testlerde bu sesleri telaffuz eden öğrencilerin büyük bölümünün peltek $\mathrm{t} / \Theta /$ ve peltek d /ð/ seslerini kullanmadıkları kaydedilmiştir. Gönüllü altı katılımcıyla yapılan yarı-yapılandırılmış mülakatlarda, öğrencilerin telaffuzun İngilizce derslerinde önemli olmadığını çünkü telaffuzu ölçen bir sınav olmadığını ya da ders içinde telaffuz hatalarının vurgulanmadığını ileri sürmüşlerdir, daha ziyade derslerde ve sınavlarda dilbilgisi hatalarının önem taşıdığını belirtmişlerdir. Bu gerekçelerle, telaffuzdan ziyade dikkatlerini bu alanlar üzerinde yoğunlaştırdıklarını ifade etmişlerdir. 
Araştırmanın Sonuçları: Testlerden elde edilen sonuçlar öğrencilerin telaffuz hatalarının düzeltilmesi konusunda öğrenmeye açık olduklarını göstermektedir. Fakat sınıf içi gözlem verilerine göre öğrencilerin henüz edindikleri bu yeni telaffuzu test esnasında kullanmalarına karşılık rutin derslerinde kullanmamaları bu davranışın içselleştirilmesi için daha fazla ve daha uzun süreli muhatap olma ve alıştırma yapmaları gerektiğine işaret etmektedir.

Öneriler: Bu yöntem daha çok "segment" düzeyinde telaffuz hataları için uygun olup oldukça sınırlı bir alana hitap etmektedir. Vurgu, ritim, tonlama, bağlı konuşma, ya da önem gibi unsurları içermemektedir. Bu sebeple bu yöntemi tek başına bütün bir telaffuz yöntemi olarak değil de telaffuz derslerine yardımcı olacak bir tamamlayıcı model olarak düşünmek gerekir, ancak devamında uzun sureli alıştırma ve dönütlerle desteklenirse Duy-seslet Yöntemi'nden etkili sonuç alınabilir. Buna ek olarak, öğrencilerin mülakatlarda ifade ettiklerini dikkate alarak, telaffuz konusunda öğretmenlerin tutumu öğrencilerin tutumların belirleyici ve etkileyici olacağını söyleyebiliriz. Öğretmenin duyduğu, düzeltmeye çalıştığı, dönüt ve pekiştireç verdiği telaffuz hataları veya telaffuz davranışları, öğrencinin de bu konuda hassasiyet geliştirmesini sağlayacaktır.

Anahtar Sözcükler: Duy-seslet Yöntemi, peltek sesler, telaffuz, telaffuz hataları 